\title{
The Use of Rubber Seed Oil as an Alternative Plant Lipid Source for Stripped Catfish (Pangasianodon hypophthalmus) Diet
}

\author{
Andi Apriany Fatmawaty ${ }^{1}$, Achmad Noerkhaerin Putra ${ }^{2}$, Aris Munandar ${ }^{2}$, Nuniek \\ Hermita $^{1}$, Mustahal ${ }^{2}$, Dodi Hermawan ${ }^{2}$, Lukman Anugrah Agung ${ }^{2}$, Arif Rahman ${ }^{2}$ and \\ Mas Bayu Syamsunarno ${ }^{2,3^{*}}$ \\ ${ }^{1}$ Department of Agroecotechnology, Faculty of Agriculture, Universitas Sultan Ageng Tirtayasa, Jl. \\ Raya Palka KM 3, Sindangsari, Pabuaran, Serang, Banten 42163, Indonesia \\ ${ }^{2}$ Study Program of Fisheries Science, Faculty of Agriculture, Universitas Sultan Ageng Tirtayasa, Jl. \\ Raya Palka KM 3, Sindangsari, Pabuaran, Serang, Banten 42163, Indonesia \\ ${ }^{3}$ Center of Excellent Local Food Innovation, Universitas Sultan Ageng Tirtayasa, Jl. Raya Palka KM \\ 3, Sindangsari, Pabuaran, Serang, Banten 42163, Indonesia
}

*Correspondence :

masbayusy@untirta.ac.id

Received : 2020-06-11

Accepted : 2021-03-09

Keywords :

Essential fatty acids, Stripped catfish, Rubber seed oil, Fat sources

\begin{abstract}
Dietary lipid in the forms of fish oil and corn oil are known as the best lipid sources. An effort to find an alternative to lipid sources other than both forms of oil can be done through the use of ts rubber seed oil. The study was conducted to evaluate rubber seed oil as a lipid source in the diet for increasing the growth of striped catfish (Pangasianodon hypophthalmus) fingerlings. A tested diet having isoprotein $(30.14 \pm 0.01 \%)$ and isoenergy (271.26 $\pm 0.08 \mathrm{DE} \mathrm{kcal} / 100 \mathrm{~g}$ ) was used in this study. Fish oil, corn oil, and rubber seed oil at a total of $3 \%$ were used as the diet's lipid sources. Rubber seed oil was added to the diet at 0,1 , and $3 \%$, respectively. After acclimatized to the experimental condition, striped catfish fingerlings $(9.72 \pm 0.01 \mathrm{~g})$ were randomly stocked in 12 aquariums (69x29x35 $\mathrm{cm}^{3}$; Volume $50 \mathrm{~L}$ ) with a density of 15 fingerlings/container and fed on the tested diet at satiation for 40 days. The use of rubber seed oil as a source of lipid in the diet does not affect the survival rate and body fat $(\mathrm{P}>0.05)$. The composition of $2 \%$ rubber seed oil in the feed gives the best growth in striped catfish fingerlings, with feed intake of $233.00 \pm 1.00 \mathrm{~g}$, a specific growth rate of $2.01 \pm 0.05 \%$ day $^{-1}$, feed efficiency of $75.45 \pm 1.18 \%$, protein efficiency ratio of $2.45 \pm 0.11 \%$ and body protein of $44.03 \pm 2.42 \%$. There is a tendency that higher rubber seed oil content in the diet, produce better the fatty acid profile in the body of the striped catfish.
\end{abstract}

\section{INTRODUCTION}

The cultivation of striped catfish (Pangasianodon hypophthalmus) is growing rapidly, among others, by utilizing peatlands (Sunarno and Marson, 2012). The support of quality seeds in sufficient quantities and commercial feed has led to an increase in the production of striped catfish culture. However, the increasing price of commercial feed reduces the profit of cultivators (Syamsunarno and Sunarno, 2016). Therefore, striped catfish farmers try to overcome the problem of feed prices by making feed independently even though 
the quality is lower than that of commercial feed (Sunarno et al., 2013). Efforts to improve the quality of farmers' feed include using local raw materials as a source of essential fats and fatty acids, protein and essential amino acids, energy sources, vitamins, and minerals (Sunarno et al., 2014; Sunarno et al., 2012).

Lipid is a non-protein source of energy as an effort to reduce feed prices. In addition, the lipid can dissolve several vitamins, and it contains essential fatty acids which will increase feed efficiency growth (NRC, 2011). Fish oil and corn oil are sources of lipids that are often used in feed. Efforts to find ingredients other than the two oils are needed to overcome fluctuations in their products which have an impact on the increase of feed prices and limitation of their use in feed (Komariyah et al., 2014).

Syamsunarno and Sunarno (2014) recommend rubber seeds as a potential local raw material for fish feed. About $80 \%$ of rubber fruits are not used as seeds (Rivai et al., 2015). The rubber seeds contain 40 - 50\% oil (Siahaan et al., 2009). After removing the oil, the protein content of the rubber seeds increases, which is assumed to be able to act as a substitute for soybean meal (Suprayudi et al., 2014a; Suprayudi et al., 2014b; Syamsunarno, 2011). The rubber seed oil also contains essential fatty acids in the form of oleic acid $(22.95 \%)$, linoleic acid (37.28\%) and linolenic acid (19.22\%) (Salimon et al., 2012). The oil content of rubber seeds is higher than soybean oil (Ramadhas et al., 2005) and is almost similar to corn oil (Hwang, 2009). The composition of essential fatty acids in rubber seed oil is $52 \%$ of the fatty acid composition (Onoji et al., 2016).

Like other plant materials, rubber seeds contain cyanide acid. These compounds dissolve in rubber seed oil, which has an impact on reducing fish growth performance (Komariyah et al., 2014; Shalihah et al., 2019). The physical treatment process through soaking and boiling rubber seed oil can reduce the content of cyanide acid (Setyawardani et al., 2013; Karima, 2015; Rahmawati et al., 2017). Furthermore, boiling rubber seeds at $100{ }^{\circ} \mathrm{C}$ for 30 minutes can reduce the cyanide acid content (Udo et al., 2018). Rubber seed oil heated at $100{ }^{\circ} \mathrm{C}$ for 60 minutes can reduce $95 \%$ of cyanide acid (Kushayadi et al., 2020). Based on this, an experiment was carried out to evaluate rubber seeds as a source of plant lipids in feed to improve the growth performance of catfish seeds.

\section{METHODOLOGY}

\section{Place and Time}

This research was conducted for 6 months in the Laboratory of Aquaculture, Faculty of Agriculture, Sultan Ageng Tirtayasa University and Baros Fish Seed Center, Serang, Banten Province.

\section{Research Materials}

The experimental materials used included an aquarium with dimensions of $69 \times 29 \times 35 \mathrm{~cm}$, a set of aeration, a water pump, a thermometer, a pH meter, a DO meter, a digital scale, a thermostat, a pellet printer, a rubber seed pressing machine, striped catfish seeds, rubber seed oil, corn oil, fish oil, commercial vitamin/ mineral premixes, commercial vitamin $\mathrm{C}$, rice bran, tapioca, fish meal, and soybean meal.

\section{Research Design}

The treatments used in this experiment were differences in the composition of rubber seed oil in the feed, namely $0,1,2$, and 3\%. Each treatment had three replications. The experimental design used was a completely randomized design (CRD).

\section{Work Procedures}

Rubber fruit originating from rubber plantations in Pandeglang and Lebak Districts were broken to obtain the rubber seeds. Afterward, the rubber seeds were washed, boiled at a temperature of $100^{\circ} \mathrm{C}$ for 30 minutes, chopped and then stored for one day (Udo et al., 2018). In the next process, the rubber seeds were dried for 30 
minutes in an oven at a temperature of $100^{\circ} \mathrm{C}$ and floured. The oil from the rubber seed flour was extracted using an automatic pressing machine. Afterward, the rubber seed oil was put into a container with a lid and was stored in the refrigerator.

Before the making of test feed was conducted, the flouring was carried out for solid feed ingredients, and then the sample was taken as the subject of proximate analysis. The test feed was composed of fish meal and soybean meal as a source of protein, rice bran as a source of carbohydrates, tapioca as an adhesive, various commercial vitamins and minerals, commercial vitamin C, fish oil, corn oil, and rubber seed oil as a source of fat (Table 1). Moreover, the protein and energy contents were made relatively the same, namely $30.14 \pm 0.01 \%$ and 271.26 $\pm 0.08 \mathrm{DE} \mathrm{kcal} / 100 \mathrm{~g}$ (Syamsunarno et al., 2011). The lipid content in the test feed was set at 3\%. Variation in fish oil and corn oil content was carried out to suit the content of rubber seed oil treatment. Furthermore, the raw materials were weighed according to the formula, mixed evenly, and made into pellets with a diameter of $3 \mathrm{~mm}$. The test feed was then dried for 24 hours in an oven at a temperature of $60^{\circ} \mathrm{C}$. After drying, the test feed was put into a labeled plastic bag, and the samples were taken as the subject of proximate analysis and its fatty acids (Table 2).

Table 1. Test feed formulation for striped catfish seeds ( $P$. hypophthalmus).

\begin{tabular}{llccc}
\hline \multirow{2}{*}{ Raw material (\%) } & \multicolumn{4}{c}{ \% Rubber Seed Oil in Feed } \\
& 0 & 1 & 2 & 3 \\
\hline Fish meal & 20.00 & 20.00 & 20.00 & 20.00 \\
Soybean meal & 36.00 & 36.00 & 36.00 & 36.00 \\
Rice bran & 26.50 & 26.50 & 26.50 & 26.50 \\
Tapioca & 12.00 & 12.00 & 12.00 & 12.00 \\
Fish oil & 1.00 & 1.00 & 1.00 & 0.00 \\
Rubber seed oil & 0.00 & 1.00 & 2.00 & 3.00 \\
Corn oil & 2.00 & 1.00 & 0.00 & 0.00 \\
Mix of vitamin and mineral mix & 2.00 & 2.00 & 2.00 & 2.00 \\
Vitamin C & 0.50 & 0.50 & 0.50 & 0.50 \\
Total & 100.00 & 100.00 & 100.00 & 100.00 \\
\hline
\end{tabular}

Table 2. Nutritional content and fatty acid profile of the test feed for striped catfish seeds (P. hypophthalmus).

\begin{tabular}{|c|c|c|c|c|}
\hline \multirow{2}{*}{ Composition } & \multicolumn{4}{|c|}{ \% Rubber Seed Oil in Feed } \\
\hline & 0 & 1 & 2 & 3 \\
\hline Crude protein (\%) & 30.15 & 30.12 & 30.13 & 30.14 \\
\hline Crude Fat (\%) & 6.43 & 6.44 & 6.42 & 6.40 \\
\hline Ash (\%) & 11.91 & 11.92 & 11.90 & 11.91 \\
\hline BETN (\%)* & 47.26 & 47.20 & 47.26 & 47.22 \\
\hline Total Energy (kcal/100g) & 271.31 & 271.32 & 271.27 & 271.14 \\
\hline DE-P ratio (kcal/gram protein) $* *$ & 9.00 & 9.01 & 9.01 & 9.00 \\
\hline Saturated fatty acids (\%) & 28.46 & 29.53 & 30.55 & 27.94 \\
\hline Monounsaturated fatty acids (\%) & 33.42 & 33.16 & 31.06 & 28.01 \\
\hline فे-3 (\%) & 3.18 & 3.36 & 4.68 & 5.78 \\
\hline 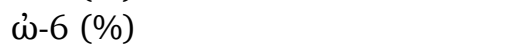 & 23.54 & 24.01 & 23.59 & 27.71 \\
\hline ف่-3/⿳亠-6 (\%) & 0.13 & 0.14 & 0.18 & 0.21 \\
\hline
\end{tabular}

Note: *BETN- Nitrogen-Free Extract; ** $1 \mathrm{~g}$ protein=3,.0 kcal DE-digestible energy; $1 \mathrm{~g}$ fat $=8,1 \mathrm{kcal}$ $\mathrm{DE}$ and $1 \mathrm{~g}$ carbohydrate $=2.5 \mathrm{kcal} \mathrm{DE}(\mathrm{NRC}, 2011)$.

The striped catfish seeds from the hatcheries were maintained in a $500 \mathrm{~L}$ volume fiber tank and given the test feed without rubber seed oil for five days as the fish acclimation period to the experimental conditions. After not being 
fed for one day, the fish were randomly entered into 12 aquariums that had been labeled with treatment, and each aquarium was equipped with a thermostat and aerator. The density of each aquarium was 15 individuals. The sample of the fish was taken from the container as the subject of proximate analysis. Feeding was carried out at satiation 3 times a day in the morning, afternoon and evening. Before feeding in the morning, the cleaning process was done at each aquarium, and the water that was wasted was replaced with water that had been deposited. Furthermore, every five days, a $50 \%$ change of the water in the aquarium was carried out. At the end of the study, the number of fish was calculated, and the biomass and fish weight was weighed to calculate the growth performance of the fish. Also, fish sampling from each treatment was conducted as the subject of proximate analysis and fatty acids. The protein, lipid, and fatty acid content of striped catfish were then analyzed using the AOAC method (2012).

The experimental test parameters observed were the amount of feed consumption (JKP) and the survival rate (S) calculated based on Handayani and Widodo (2010, and the specific growth rate (LPS), feed efficiency (EP) and protein efficiency ratio (REP) calculated based on Nates (2016). The formula for each parameter is as follows:

$\mathrm{JKP}(\mathrm{g})=\mathrm{W}_{0}-\mathrm{W}_{1}$

Where:

$\mathrm{W}_{0} \quad=$ initial feed weight $(\mathrm{g})$

$\mathrm{W}_{1} \quad$ = final feed weight $(\mathrm{g})$

LPS (\%day) $=\frac{\ln (W t)-\ln (W 0)}{t}$

Where:

$\mathrm{W}_{\mathrm{t}} \quad$ = fish final average weight $(\mathrm{g})$

$\mathrm{W}_{0} \quad=$ fish initial average weight $(\mathrm{g})$

$\mathrm{t} \quad=$ cultivation period (day)

$\mathrm{EP}=\frac{(\mathrm{Bt}+\mathrm{Bd})-\mathrm{Bo}}{\mathrm{F}} \times 100 \%$

Where:

$\mathrm{B}_{\mathrm{t}} \quad=$ fish final biomass $(\mathrm{g})$

$\mathrm{B}_{\mathrm{d}} \quad=$ dead fish absolute biomass $(\mathrm{g})$

$\mathrm{B}_{0} \quad=$ fish initial biomass $(\mathrm{g})$

$\mathrm{F} \quad \quad=$ feed consumed by fish $(\mathrm{g})$
REP $=\frac{W t-W o}{P i} \times 100 \%$

Where:

$\mathrm{W}_{\mathrm{t}} \quad$ = fish final average weight $(\mathrm{g})$

$\mathrm{W}_{0} \quad=$ fish initial average weight $(\mathrm{g})$

$\mathrm{Pi} \quad=$ weight of protein consumed $(\mathrm{g})$

$\mathrm{S}=\frac{\Sigma \mathrm{fish} \text { at the end of cultivation }}{\Sigma \text { fish at the beginning of cultivation }} \times 100 \%$

\section{Data Analysis}

Data for each test parameter included the amount of feed consumption, protein efficiency ratio, specific growth rate, feed efficiency, survival rate, and protein and body fat contents which were statistically analyzed using the variancebased fingerprint method (ANOVA) with a $95 \%$ confidence interval. If the test between treatments was significantly different, it was continued with the Duncan test. The fatty acid content of fish was then analyzed descriptively.

\section{RESULTS AND DISCUSSION}

Based on Table 3, fish feed intake decreases along with the increase in rubber seed oil $(\mathrm{P}<0.05)$. The lower unsaturated fatty acids along with the increase in rubber seed oil in the feed are thought to reduce the palatability of the test feed (Table 2). Sargent et al. (2002) state that low unsaturated fatty acids will be easily oxidized and cause a decrease in feed palatability. The same thing happens to goldfish (Shalihah et al., 2019) and striped catfish (Suprayudi et al., 2014b). A decrease in appetite in tilapia is observed in the use of rubber seed flour of more than 60\% in feed (Lee and Wendy, 2017). In addition, the presence of cyanide acid in rubber seed oil can reduce feed palatability (Kushayadi et al., 2020). The content of cyanide acid in the feed is 8.25 - 43.12 ppm (Deng et al., 2017). However, it is suspected that the striped catfish seeds could tolerate the cyanide acid content in the rubber seed oil during maintenance. This is indicated by the survival rate that does not differ between treatments $(\mathrm{P}>$ 0.05). Moreover, the increase in the concentration of cyanide in feed causes high mortality in fish (Komariyah et al., 
2014; Shalihah et al., 2019). The cyanide content of $1.27-5.05 \mathrm{mg} / \mathrm{kg}$ does not affect on the survival rate in goldfish (Fawole et al., 2016), and in general the mortality in freshwater fish occurs at cyanide content at above $13.87 \mathrm{mg} / \mathrm{kg}$ (Sharma et al., 2014). The minimum lethal dose of cyanide acid given via feed to land animals is $50-90 \mathrm{mg} / \mathrm{kg}$ (Newhouse and Chiu, 2010).

Table 3. The growth performance of striped catfish seeds during the cultivation period.

\begin{tabular}{lllll}
\hline \multirow{2}{*}{ Parameter** } & \multicolumn{4}{c}{ \% Rubber Seed Oil in Feed * } \\
& \multicolumn{1}{c}{0} & \multicolumn{1}{c}{1} & \multicolumn{1}{c}{2} & \multicolumn{1}{c}{3} \\
\hline JKP (g) & $237.00 \pm 1.00^{\mathrm{a}}$ & $237.00 \pm 1.53^{\mathrm{a}}$ & $233.00 \pm 1.00^{\mathrm{b}}$ & $227.00 \pm 1.00^{\mathrm{c}}$ \\
REP (\%) & $1.92 \pm 0.18^{\mathrm{c}}$ & $2.06 \pm 0.23^{\mathrm{b}}$ & $2.45 \pm 0.11^{\mathrm{a}}$ & $1.80 \pm 0.15^{\mathrm{c}}$ \\
LPS (\%day $\left.{ }^{-1}\right)$ & $1.77 \pm 0.03^{\mathrm{c}}$ & $1.86 \pm 0.04^{\mathrm{b}}$ & $2.01 \pm 0.05^{\mathrm{a}}$ & $1.75 \pm 0.05^{\mathrm{c}}$ \\
EP (\%) & $60.63 \pm 2.93^{\mathrm{bc}}$ & $65.68 \pm 4.13^{\mathrm{b}}$ & $75.45 \pm 1.18^{\mathrm{a}}$ & $58.20 \pm 1.49^{\mathrm{c}}$ \\
S (\%) & $95.56 \pm 3.85$ & $95.56 \pm 3.85$ & $97.78 \pm 3.85$ & $95.56 \pm 3.85$ \\
\hline
\end{tabular}

Where: *Different superscript letters indicate significantly different values $(\mathrm{P}<0,05)$; ** JKP: the amount of feed consumption, REP: protein efficiency ratio, LPS: specific growth rate, EP: feed efficiency and S: survival rate.

Table 4. Crude protein and crude fat contents (\%) in the body of striped catfish at the end of the cultivation

\begin{tabular}{lllll}
\hline \multirow{2}{*}{ Parameter } & \multicolumn{4}{c}{ \% Rubber Seed Oil in Feed } \\
& 0 & 1 & 2 & \multicolumn{1}{c}{3} \\
\hline Crude protein & $38.56 \pm 2.44^{\mathrm{ab}}$ & $37.56 \pm 3.20^{\mathrm{b}}$ & $44.03 \pm 2.42^{\mathrm{a}}$ & $41.56 \pm 3.43^{\mathrm{ab}}$ \\
Crude fat & $35.13 \pm 2.42$ & $35.19 \pm 2.74$ & $36.22 \pm 2.36$ & $38.25 \pm 2.44$ \\
\hline
\end{tabular}

Note: * Different superscript letters indicate significantly different values $(\mathrm{P}<0,05)$.

The growth of striped catfish seeds increases until a concentration of $2 \%$ rubber seed oil and decreases at a concentration of $3 \%(\mathrm{P}<0.05)$. This is related to the adequacy of the essential fatty acids of feed in rubber seed oil $2 \%$ to the increase of the growth rate. The adequacy of essential fatty acids increases fluidity as a medium for transferring nutrients and enzymes to the cell membrane (Steffens and Wirth, 2007). Striped catfish need $\omega \dot{\omega}-6$ fatty acids more than $\dot{\omega}-3$ to accelerate their growth (Asdari et al., 2011; Juliana et al., 2016). ఏ่-6 fatty acids are mostly found in vegetable oils, and they can increase the growth rate in African catfish (Clarias gariepinus) (Szabó et al., 2009). The results of the growth of striped catfish seeds in 0 and $3 \%$ rubber seed oil, which are not significantly different, indicate that fish oil and corn oil could be replaced by rubber seed oil which contains $\boldsymbol{\omega}-6$, but the feed contains cyanide acid which can suppress the release of oxygen in the fish blood, which causes a decrease in metabolism (Komariyah et al., 2014).
Cyanide acid poisoning is characterized by a low feed efficiency value (Satimehin and Tiamiyu, 2019). The fish are thought to have cyanide poisoning in 3\% rubber seed oil, so they are unable to use feed efficiently due to low feed intake, feed efficiency and protein efficiency when compared to $2 \%$ rubber seed oil (P $<0.05)$. The low efficient ratio of protein results in low fish growth (Munisa et al., 2015).

Cyanide acid of rubber seed affects the storage of feed protein in the body (Oluodo et al., 2018). The protein in the fish body in $2 \%$ rubber seed oil gives a significant result with other treatments $(\mathrm{P}$ $<0.05$ ) (Table 4). The increase in rubber seed oil is thought to increase antinutritional substances that inhibit metabolic processes and nutrient storage in fish bodies (Kushayadi et al., 2020). However, the use of rubber seed oil does not affect the body fat content of striped catfish seeds at the end of the cultivation (P> 0.05). Body fat in fish is not influenced by differences in the source of fat in the feed (Turchini et al., 2013). Feed 
oil is thought to be used to fulfill metabolic energy so that protein can be used for growth (Syamsunarno et al., 2011). Moreover, feed protein should be used for replacement of damaged tissue and growth and not be used as an energy source (Putra, 2017).

Table 5. Composition of the fatty acid in the body of the striped catfish at the end of the cultivation (\%).

\begin{tabular}{|c|c|c|c|c|}
\hline \multirow{2}{*}{ Fatty acid } & \multicolumn{4}{|c|}{ \% Rubber Seed Oil in Feed } \\
\hline & 0 & 1 & 2 & 3 \\
\hline $12: 0$ & 0.54 & 0.62 & 0.69 & 0.79 \\
\hline $14: 0$ & 5.72 & 5.98 & 5.82 & 6.14 \\
\hline $15: 0$ & 0.24 & 0.26 & 0.25 & 0.24 \\
\hline $16: 0$ & 29.50 & 30.98 & 29.50 & 29.36 \\
\hline $17: 0$ & 0.31 & 0.33 & 0.31 & 0.30 \\
\hline $18: 0$ & 6.17 & 6.60 & 6.49 & 6.96 \\
\hline $20: 0$ & 0.18 & 0.19 & 0.17 & 0.16 \\
\hline $21: 0$ & 0.00 & 0.00 & 0.00 & 0.00 \\
\hline $22: 0$ & 0.08 & 0.08 & 0.07 & 0.08 \\
\hline $23: 0$ & 0.02 & 0.03 & 0.02 & 0.03 \\
\hline $24: 0$ & 0.06 & 0.06 & 0.06 & 0.05 \\
\hline $14: 1$ & 0.04 & 0.09 & 0.09 & 0.04 \\
\hline $16: 1$ & 1.40 & 1.44 & 1.35 & 1.32 \\
\hline $17: 1$ & 0.03 & 0.03 & 0.15 & 0.15 \\
\hline $18: \ln 9$ & 29.08 & 30.52 & 27.59 & 28.69 \\
\hline $20: 1$ & 0.67 & 0.71 & 0.62 & 0.59 \\
\hline $24: 1$ & 0.04 & 0.04 & 0.04 & 0.04 \\
\hline $18: 2 \mathrm{n} 6$ & 11.40 & 11.64 & 11.10 & 11.93 \\
\hline $20: 3 n 6$ & 0.57 & 0.62 & 0.59 & 0.60 \\
\hline $20: 4 \mathrm{n} 6$ & 0.45 & 0.54 & 0.50 & 0.48 \\
\hline $20: 3 n 6$ & 0.57 & 0.62 & 0.59 & 0.60 \\
\hline $18: 3 n 3$ & 0.69 & 0.78 & 0.99 & 1.34 \\
\hline $20: 5 n 3$ & 0.21 & 0.20 & 0.17 & 0.17 \\
\hline $22: 6 n 3$ & 0.57 & 0.52 & 0.44 & 0.46 \\
\hline$\Sigma$ saturated fatty acids & 42.82 & 45.13 & 43.38 & 44.11 \\
\hline$\Sigma$ monounsaturated fatty acids & 31.26 & 32.83 & 29.84 & 30.83 \\
\hline$\Sigma \grave{\omega}-6$ & 12.63 & 13.01 & 12.40 & 13.22 \\
\hline$\Sigma \omega \dot{\omega}-3$ & 1.47 & 1.50 & 1.60 & 1.97 \\
\hline$\omega ่-6 / \omega ่-3$ & 8.59 & 8.67 & 7.75 & 6.71 \\
\hline$\omega-3 / \omega-6$ & 0.12 & 0.12 & 0.13 & 0.15 \\
\hline
\end{tabular}

Table 5 presents fatty acid profiles in the body of striped catfish seeds in various rubber seed oils. The differences in the composition of the dietary lipid result in the differences in the fatty acid profile of the fish body. The fatty acid in the body of striped catfish seeds at the end of the cultivation is dominated by 16: 0 fatty acids. The high level of fatty acids in the body is the characteristic of Teleostei fish and other freshwater fish (Asdari et al., 2011; Dernekbaş1 et al., 2017). The high $\omega$-9 content in the fish body is thought to be related to the higher $\omega-3$ composition of the feed with the addition of rubber seed oil. The difference in $\omega$ - 3 content affects the $\omega$ - 9 content of the body (Mukti et al., 2014). The high- 3 content causes a low $\omega$ - 9 composition in the body (Tocher, 2010). Moreover, monounsaturated fatty acids and saturated fatty acids are the dominant body fatty acids in catfish (Juliana et al., 2016). Rubber seed oil also contains a lot of oleic, linoleic and linolenic and 16: 0 and 18: 0 (Eka et al., 2010; Karima, 2015). In $2 \%$ and $3 \%$ rubber seed oil, fish body contains 20: $5 \mathrm{n}$ -3 and 22: $6 n-3$ fatty acids lower than 
in the other treatments. Striped catfish are thought to be able to convert 18: $3 n-3$ fatty acids to 20 : $5 n-3$ and 22: $6 n-3$. Striped catfish do not need 18: $3 n-3$ unsaturated fatty acids for growth because they have elongase and desaturase enzymes so that striped catfish need 18 : $2 n-6$. This is shown in the high $\omega-6$ fatty acid composition of striped catfish at the end of the cultivation. The use of high vegetable oil in feed results in a decrease in monounsaturated fatty acids and $\omega$ - 3 and an increase in fish bodies (Dernekbaş1 et al., 2017; Ayisi et al., 2018). The ratio of $\omega-3 / \hat{\omega}-6$ in the body of striped catfish seeds is influenced by the ratio of $\omega-3 / \omega$ 6 in the feed. The higher the content of the rubber seed oil results in a relatively similar value of $\boldsymbol{\omega}-3 / 6-6$ fatty acid ratio in the feed and in the body of the striped catfish. Moreover, the use of vegetable oil in feed results in the low $\omega-3 / \dot{\omega}-6$ content in the fish body when compared to the use of fish oil (Piedecausa et al., 2007). Striped catfish require a low $\omega \dot{\omega}-3 / \hat{\omega}-6$ feed ratio to produce a high level of fish growth (Asdari et al., 2011). Meanwhile, the ratio of $\boldsymbol{\omega}-6 / \hat{\omega}-3$ in fish bodies at the end of the cultivation for all treatments is 6.71-8.59. According to Kartono (2012), a ratio of $\omega$ $6 / \hat{\omega}-3$ of $4.0-8.1$ can prevent chronic degenerative diseases in humans.

Apart from the content of cyanide acid in the feed which is thought to be tolerated by striped catfish seeds, the optimal media water quality results in the survival rate of striped catfish seeds between treatments not significantly different. The results of water quality measurements for 40 days of cultivation were DO of $5.16-6.00 \mathrm{mg} / \mathrm{L}$, ammonia of $0.013-0.015 \mathrm{mg} / \mathrm{L}$, a water temperature of $29-30^{\circ} \mathrm{C}$ and water $\mathrm{pH}$ of $7.3-7.5$. The results of these measurements are in accordance with BSN (2000) that the optimal water quality for striped catfish cultivation is at a temperature of $27-30^{\circ} \mathrm{C}$, $\mathrm{pH}$ 6.50-8.50, and DO> $5 \mathrm{mg} / \mathrm{L}$.

\section{CONCLUSION}

Rubber seed oil can be used as an alternative source of plant lipids in the feed if the cyanide content can be removed. The use of $2 \%$ rubber seed oil in the formula feed gives the best growth in striped catfish seeds, and there is a tendency that the fatty acid profile of striped catfish is getting better in line with the increase in the content of rubber seed oil in the feed.

\section{ACKNOWLEDGMENT}

The authors would like to offer special thanks to IsDB (Islamic Development Bank), Universitas Sultan Ageng Tirtayasa for the research grant on the Basic Research scheme of Excellence of Science and Technology Year 2018. The authors would also thank the Baros Fish Seed Center, Serang Banten Province for permitting the accomplishment of this research.

\section{REFERENCES}

Asdari, R., Aliyu-Paiko, M., Hashim, R. and Ramachandran, S., 2011. Effects of different dietary lipid sources in the diet for Pangasius hypophthalmus (Sauvage, 1878) juvenile on growth performance, nutrient utilization, body indices and muscle and liver fatty acid composition. Aquaculture nutrition, 17(1), pp.44-53. https://doi.org/10.1111/j.13652095.2009.00705.x.

AOAC (Association of Official Analytical Chemists), 2012. Official methods of analysis $19^{\text {th }} \mathrm{ed}$. Association of Official Analytical Chemists, Airlington.

Ayisi, C.L., Zhao, J. and Wu, J.W., 2018. Replacement of fish oil with palm oil: Effects on growth performance, innate immune response, antioxidant capacity and disease resistance in Nile tilapia (Oreochromis niloticus). PLoS ONE, 13(4), pp.1-17. https://doi.org/10. 1371/journal.pone.0196100

BSN (Badan Standarisasi Nasional), 2000. SNI 01-6483.4-2000: Produksi benih ikan patin siam (Pangasius hyphthalmus) kelas benih sebar. 
Badan Standarisasi Nasional Indonesia, Jakarta. p.1-13.

Deng, J.M., Wang, Y., Chen, L.Q., Mai, K.S., Wang, Z. and Zhang, X., 2017. Effects of replacing plant proteins with rubber seed meal on growth, nutrient utilization and blood biochemical parameters of tilapia (Oreochromis niloticus $\times$ O. aureus). Aquaculture nutrition, 23(1), pp.3039. https://doi.org/10.1111/anu.12 355.

Dernekbaşı, S., Karayücel, I. and Akyüz, A.P., 2017. Effect of diets containing laurel seed oil on growth and fatty acid composition of rainbow trout, Oncorhynchus mykiss. Aquaculture Nutrition, 23(2), pp.219-227. https: //doi.org/10.1111/anu.12382

Eka, H.D., Tajul Aris, Y. and Wan Nadiah, W.A., 2010. Potential use of Malaysian rubber (Hevea brasiliensis) seed as food, feed and biofuel. International food research journal, 17(3), pp.527-534. http:// www.ifrj.upm.edu.my/volume-172010.html

Fawole, F.J., Sahu, N.P., Jain, K.K., Gupta, S., Shamna, N., Phulia, V. and Prabu, D.L., 2016. Nutritional evaluation of protein isolate from rubber seed in the diet of Labeo rohita: Effects on growth performance, nutrient utilization, whole body composition and metabolic enzymes activity. Animal Feed Science and Technology, 219, pp.189-199. https://doi.org/10.10 16/j.anifeedsci.2016.06.014.

Handayani, H. and Widodo, W., 2010. Nutrisi Ikan. UMM Press, Malang. p. 271.

Hwang, J., 2009. Diets with corn oil and/or low protein increase acute acetaminophen hepatotoxicity compared to diets with beef tallow in a rat model. Nutrition Research and Practice, 3(2), pp.95-101. https://doi.org/10.4162/nrp.2009. 3.2 .95

Juliana, B.R., Vanessa, B.V., Tatiana, E., Claudia, S.R. and Bernardo, B.,
2016. Fatty acid composition of fillets of silver catfish fed on sunflower oil and linseed oil. International Food Research Journal, 23(6), pp.2453-2458. http://www.i frj.upm.edu.my/volume-23-2016.ht $\mathrm{ml}$

Karima, R., 2015. Kualitas minyak biji karet sebagai minyak pangan alternatif pasca penghilangan HCN. Jurnal Riset Industri Hasil Hutan, 7(2), pp.17-22. http://dx.doi.org/1 $0.24111 /$ jrihh.v7i2.1227

Kartono, D., 2012. Ringkasan - Angka Kecukupan Gizi (AKG) yang dianjurkan bagi Orang Indonesia 2012. In Widyakarya Nasional Pangan dan Gizi X: Presentasi dan Poster/M.Y.E. Soekatri, S. Muslimatun, Purwanto, M. Ariani, Hardinsyah, Y. Egayanti, dan L.B. Kardono (Ed.). - Jakarta: LIPI Press.

Komariyah, S., Suprayudi, M.A. and Jusadi, D., 2014. Preliminary study of rubber seed Hevea brasiliensis oil utilization for tilapia diet. Jurnal Akuakultur Indonesia, 13(1), pp.6167. https://doi.org/10.19027/jai.13 .61-67.

Kushayadi, A.G., Suprayudi, M.A., Jusadi, D. and Fauzi, I.A., 2020. Evaluation of rubber seed oil as lipid source in red tilapia (Oreochromis sp.) diet. Aquaculture Research, 51(1), pp.114-123. https://doi.org/10.11 11/are.14352

Lee, S.W. and Wendy, W., 2017. Malaysian rubber (Hevea brasiliensis) seed as alternative protein source for red hybrid tilapia, Oreochromis sp., farming. AACL Bioflux, 10(1), pp.32-37. http://www.bioflux.com.ro/docs/2 017.32-37.pdf

Mukti, R.C., Utomo, N.B.P. and Affandi, R., 2014. Penambahan minyak ikan pada pakan komersial terhadap pertumbuhan Anguilla bicolor bicolor. Jurnal Akuakultur Indonesia, 13(1), pp.54-60. https://doi.org/10 .19027/jai.13.54-60 
Munisa,Q., Subandiyono and Pinandoyo., 2015. Pengaruh kandungan lemak dan energi yang berbeda dalam pakan terhadap pemanfaatan pakan dan pertumbuhan patin (Pangasius pangasius). Journal of Aquaculture Management and Technology, 4(3), pp.12-21. https://ejournal3.undip. ac.id/index.php/jamt/article/view/ 9457

Nates, S.F., 2016. Aquafeed formulation. Elsevier Inc, Oxford. p.303.

Newhouse, K. and Chiu, N., 2010. Toxicological review of hydrogen cyanide and cyanide salts. U.S. Environmental Protection Agency, Washington DC. p.153.

NRC National Research Council, 2011. Nutrient Requirements of Fish and Shrimp. Washington, DC: The National Academies Press. https://doi.org/10.17226/13039

Oluodo, L.A., Huda, N. and Komilus, C.F., 2018. Potential utilization of rubber seed meal as feed and food potential utilization of rubber seed meal as feed and food. International Journal of Engineering \& Technology, 7(4.43), pp.64-71. http://dx.doi.or $\mathrm{g} / 10.14419 /$ ijet.v7i4.43.25821

Onoji, S.E., Iyuke, S.E. and Igbafe, A.I., 2016. Hevea brasiliensis (rubber seed) Oil: Extraction, characterization, and kinetics of thermo-oxidative degradation using classical chemical methods. Energy and fuels, 30(12), pp.10555-10567. https://doi.org/10.1021/acs.energy fuels.6b02267

Piedecausa, M.A., Mazón, M.J., García García, B. and Hernández, M.D., 2007. Effects of total replacement of fish oil by vegetable oils in the diets of sharpsnout seabream (Diplodus puntazzo). Aquaculture, 263(1-4), pp.211-219. https://doi.org/10.10 16/j.aquaculture.2006.09.039

Putra, A.P., 2017. Effect Prebiotic on Growth and Feed Retension of Tilapia. Jurnal Perikanan dan Kelautan, 7(1), pp.18-24. http://dx. doi.org/10.33512/jpk.v7i1.1947
Rahmawati, L., Ellya, H. and Iswahyudi, H., 2017. Kandungan hidrogen sianida (HCN) daging biji karet pada perlakuan teknik reduksi. Jurnal Teknologi Agro-Industri, 4(2), pp.53-60. https://doi.org/10.3412 8/jtai.v4i2.49

Ramadhas, A.S., Jayaraj, S. and Muraleedharan, C., 2005. Biodiesel production from high FFA rubber seed oil. Fuel, 84(4), pp.335-340. https://doi.org/10.1016/j.fuel.200 4.09.016

Rivai, R.R., Damayanti, F. and Handayani, M., 2015. Potential development of rubber seed (Hevea brasiliensis) as an alternative food in North Bengkulu. In Prosiding seminar nasional masyarakat biodiversitas Indonesia, 1(2), pp.343-346. https:/ /doi.org/10.13057/psnmbi/m0102 29

Salimon, J., Abdullah, B.M. and Salih, N., 2012. Rubber (Hevea brasiliensis) seed oil toxicity effect and linamarin compound analysis. Lipids in Health and Disease, 11(74), pp.1-8. https:/ /doi.org/10.1186/1476-511X-1174.

Sargent, J.R., Tocher, D.R. and Bell, J.G., 2002. The Lipid. In: Halver, J.R., and Hardy, R.W.(Eds). Fish Nutrition $\quad 3^{\text {rd }} \quad$ (pp.182-257). Academia Press, California.

Satimehin, F.P.D. and Tiamiyu, L.O., 2019. Growth responses of Clarias gariepinus fingerlings fed differently boiled periods of rubber (Hevea brasilensis) leaves-based diets. Egyptian Journal of Basic and Applied Sciences, 6(1), pp.187-194. https:// doi.org/10.1080/2314808x.2019.1 693754.

Setyawardani, D.A., Alkausar, H.S. and Fadhilah, U.R., 2013. Pengolahan Biji Karet Sebagai Bahan Baku Pembuatan Minyak Pangan (Edible Oil). EKUILIBRIUM Journal of Chemical Engineering, 12(1), pp.2326. https://doi.org/10.20961/ekuili brium.v12i1.24900 
Shalihah, H., Munandar, A. and Syamsunarno, M.B., 2019. Penggunaan minyak biji karet (Hevea brasiliensis) dalam pakan untuk menunjang kinerja pertumbuhan ikan mas (Cryprinus carpio). DEPIK Jurnal Ilmu-Ilmu Perairan, Pesisir dan Perikanan, 8(1), pp.26-35. https://doi.org/10. 13170/depik.8.1.13100.

Sharma, B.B., Saha, R.K. and Saha, H., 2014. Effects of feeding detoxified rubber seed meal on growth performance and haematological indices of Labeo rohita (hamilton) fingerlings. Animal Feed Science and Technology, 193, pp.84-92. https://doi.org/10.1016/j.anifeedsc i.2014.03.008

Siahaan, S., Setyaningsih, D. and Hariyadi, 2009. Potensi pemanfaatan biji karet (Hevea brasiliansis Muell.Arg) sebagai sumber energi alternatif biokerosin. Teknologi industri pertanian, 19(3), pp.145-151. https://journal.ipb.ac.i d/index.php/jurnaltin/article/view $/ 1777$

Steffens, W. and Wirth, M., 2007. Influence of nutrition on the lipid quality of pond fish: Common carp (Cyprinus carpio) and tench (Tinca tinca). Aquaculture International, 15, pp.313-319. https://doi.org/10. 1007/s10499-007-9088-z.

Sunarno, M.T.D., Sulhi, M., Suryaningrum, L.S. and Wilakstanti, M., 2014. Penelitian pengembangan pakan efisien dan ekonomis berbasis bahan baku lokal untuk budidaya ikan patin (Pangasianodon hypopthalmus) di Kabupaten Kampar, Riau. In Prosiding forum inovasi teknologi akuakultur, pp.587-595. http://ejournal-balitba ng.kkp.go.id/index.php/fita/article /view/3767

Sunarno, M.T.D., Sulhi, M., Samsudin, R. and Heptarina, D., 2012. Petunjuk teknis teknologi pakan ikan: ekonomis dan efisien berbasis bahan baku lokal. IPB Press, Bogor. p.54.
Sunarno, M.T.D., Sulhi. M. and Suryaningrum, L.H., 2013. Kajian pabrik pakan ikan lokal dalam mendukung industrialisasi budidaya patin (Pangasius sp.) di Kabupaten Kampar Provinsi Riau. In Prosiding Forum inovasi teknologi akuakultur, pp.371-379. http://ejournal-balitba ng.kkp.go.id/index.php/fita/article /view/4268

Sunarno, M.T.D. and Marson, 2012. Swampy area for development of patin culture. Proceeding international conference on Indonesia inland Water III, pp. 57-63.

Suprayudi, M.A., Inara, C., Ekasari, J., Utomo, N., Haga, Y., Takeuchi, T. and Satoh, S., 2014. Preliminary nutritional evaluation of rubber seed and defatted rubber seed meals as plant protein sources for common carp Cyprinus carpio L. juvenile diet. Aquaculture research, 46(12), pp.2972-2981. https://doi.org/10. 1111/are. 12452

Suprayudi, M.A., Irawan, W.S. and Utomo, N.B.P., 2014. Evaluation of incubated defatted rubber seed meal with sheep rumen liquor for Pangasius diet. Jurnal Akuakultur Indonesia, 13(2), pp.146-151. https://doi.org/10.19027/jai.13.14 6-151

Syamsunarno, M.B., 2011. Evaluasi tepung biji karet Hevea brasiliensis sebagai bahan baku pakan ikan lele (Clarias sp.). Tesis. Institut Pertanian Bogor, Bogor.

Syamsunarno, M.B., Mokoginta, I. and Jusadi, D., 2011. Pengaruh berbagai rasio energi protein pada pakan iso protein $30 \%$ terhadap kinerja pertumbuhan benih ikan patin (Pangasius hypophthalmus). Jurnal Riset Akuakultur, 6(1), pp.63-70. https://doi.org/10.15578/jra.6.1.2 011.63-70

Syamsunarno, M.B. and Sunarno, M.T.D., 2014. Kajian biji karet (Hevea brasiliensis) sebagai kandidat bahan baku pakan ikan. Jurnal ilmu pertanian dan perikanan, 3(2), 
pp.135-142. http://umbidharma. org/jipp

Syamsunarno, M.B. and Sunarno, M.T.D., 2016. Budidaya ikan air tawar ramah lingkungan untuk mendukung keberlanjutan penyediaan ikan bagi masyarakat. In Seminar Nasional Perikanan Dan Kelautan. Pembangunan Perikanan Dan Kelautan Dalam Mendukung Kedaulatan Pangan Nasional. Bandar Lampung, pp.1-15. http://bidtangkap-dpkpklu.lombok utarakab.go.id/homepage/downloa d_file/BudidayaIkanRamahLingkun gan.pdf

Szabó, A., Romvári, R., Szathmári, L., Molnár, T., Locsmándi, L., Bázár, G., Molnár, E., Horn, P. and Hancz, C., 2009. Effects of dietary vegetable oil supplementation on fillet quality traits, chemical and fatty acid composition of African catfish (Clarias gariepinus). Archives Animal Breeding, 52(3), pp.321-333. https://doi.org/10.5194/aab-52321-2009.

Tocher, D.R., 2010. Fatty acid requirements in ontogeny of marine and freshwater fish. Aquaculture Research, 41(5), pp.717-732. https: //doi.org/10.1111/j.1365-2109.20 08.02150.x.

Turchini, G.M., Hermon, K., Cleveland, B.J., Emery, J.A., Rankin, T. and Francis, D.S., 2013. Seven fish oil substitutes over a rainbow trout grow-out cycle: I) Effects on performance and fatty acid metabolism. Aquaculture Nutrition, 19(s1), pp.82-94. https://doi.org/1 0.1111 /anu.12046.

Udo, M.D., Ekpo, U. and Ahamefule, F.O., 2018. Effects of processing on the nutrient composition of rubber seed meal. Journal of the Saudi Society of Agricultural Sciences, 17(3), pp.297301. https://doi.org/10.1016/j.jssa s.2016.06.001 